\title{
Application of Lemongrass (Cymbopogon citratus) as a Functional Food Ingredient with Alpha- Glucosidase Inhibitory Activity
}

\author{
Filiana Santoso \\ Department of Food Technology \\ Swiss German University \\ Tangerang, Indonesia \\ filiana.santoso@sgu.ac.id
}

\author{
Jonathan Winarno \\ Department of Food Technology \\ Swiss German University \\ Tangerang, Indonesia \\ jonathan_winarno@yahoo.com
}

\author{
Maria D.P.T. Gunawan-Puteri* \\ Department of Food Technology \\ Swiss German University \\ Tangerang, Indonesia \\ maria.gunawanputeri@sgu.ac.id
}

\begin{abstract}
Lemongrass showed potential for development as a functional ingredient due to the presence of alpha-glucosidase inhibitors (AGIs) and lower cytotoxic activity. However, studies regarding the application of lemongrass as ingredient have yet to be conducted to observe stability against heat treatment in processing model as well as its interaction with other ingredients. This study aimed to assess the AGI stability against rapid and long-term heating to model pasteurization and incubation, respectively. Moreover, the impact of lemongrass on the physical and sensory qualities of two dairy products was evaluated. The AGI activity was measured using rat intestinal glucosidase inhibition assay and sensory evaluation was performed using the Hedonic test. Stability testing against heating as applied in the ice cream and yoghurt production showed that heating decreased AGI activities, where longer heating intensified the effect vigorously. Noteworthy was that a higher extract amount lessened the damaging effect significantly. Yoghurt fortified with $1,500 \mathrm{mg} / \mathrm{L}$ of lemongrass extract failed to form. Fortification of lemongrass extract reduced viscosity in both ice cream and yoghurt, increased meltdown rate and reduced overrun value in ice cream. Varied concentrations of lemongrass added in ice cream had no significant effect on the sensory acceptance. Hence, lemongrass showed high potential as a functional ingredient for ice cream.
\end{abstract}

Keywords-lemongrass, a-glucosidase inhibitor, ingredient, ice cream, yoghurt

\section{INTRODUCTION}

Alpha glucosidase inhibitors (AGIs) are substances that inhibit the activities of $\alpha$-glucosidase enzymes in the intestine, and consequently delay the absorption of sugar from the gut [1]. Therefore, effective AGIs may serve as chemotherapeutic agents for clinical use in the treatment of diabetes. The effects of monotherapy with AGIs for patients with type 2 diabetes were reviewed [2] and it was found that AGIs exhibited significant beneficial effects on glycemic control and post load insulin levels, which indicated the possible use of AGIs as a first-line agent or in combination with other antihyperglycemic drugs. No evidence of an effect on mortality or morbidity was observed. In recent decades, natural products exploration as potential resources for health functions has drawn special interest of the pharmaceutical research community, since they may serve as frontier medicines if they meet scientific and regulatory testing criteria [3]. In the prevention and treatment of diabetes, plant-based medicines and functional foods affecting beneficial physiological effects have gained high interest in the last decades. Recent studies have shown Indonesian medicinal plants as sources of alpha glucosidase inhibitors for diabetic treatments [4-8], and our previous study revealed lemongrass (Cymbopogon citratus) as a potential source of AGIs [9].

Activities expressed by its aqueous extract supported lemongrass utilization as a functional food ingredient and further supporting research also indicated its low cytotoxicity and AGI activities stability against heat treatment in extraction, evaporation, spray drying process, and storage [10]. Further optimization of lemongrass pre-treatment and extraction has been done to optimize the AGIs activities and stability [10-11]. These studies suggested good AGI stability of lemongrass in various processes of extract preparation. However, a functional ingredient applied in a food product will undergo various processes during the food production like pasteurization or incubation. Currently, there is no report yet about AGI stability of lemongrass extract against hightemperature heating treatment commonly used in the production of dairy products.

As the awareness and interest in the relation between diet and health in Indonesia increases, the demand of healthy and functional foods increases as well, so Indonesian people tend to include more functional foods and supplements in their daily intake. Though functional activity is an important aspect in the application of a functional ingredient in food, the ingredient impact to sensory characteristic and acceptance, as well as its application practicality for the food product must be studied. However, research on the application of lemongrass as a functional ingredient in dairy products has not yet been conducted.

The aim of the investigation was to assess whether rapid and long-term heating, as used in pasteurization and incubation, affects the AGI activities of lemongrass aqueous extract. The impact of the ingredient lemongrass to the physical and sensory qualities of two food models, yoghurt and ice cream, was also evaluated. The two dairy products were chosen as they have similar ingredients, but differ in the production process. Moreover, two forms of lemongrass, aqueous extract and dry powder, were evaluated to assess the form with higher AGI activity. 


\section{METHODS}

The study was conducted at Swiss German University, Tangerang, Indonesia, from March to August 2017.

\section{A. Chemicals and Reagents}

Dimethyl sulfoxide, EDTA, Triton X, sodium phosphate, potassium phosphate, $\mathrm{K} \cdot \mathrm{Na}$-tartaric acid, sucrose, and tris(hydroxymethyl)aminomethane were purchased from Merck (Darmstadt, Germany). Hydrochloric acid was obtained from PT. Smartland (Indonesia). Potassium dihydrogen phosphate was provided by Sinopharm Chemical Reagent Co, (Shanghai, PRC). Rat intestinal acetone powder was from Sigma-Aldrich (Germany). Glucose kit was purchased from Wako (Japan). Distilled water provided by PT. Sumber Abadi (Tangerang, Indonesia) was used throughout the study.

\section{B. Food Matrices}

Sun-dried lemongrass (Cymbopogon citratus) was obtained from Karang Anyar Lereng Lawu (Solo, Indonesia). UHT full cream milk was supplied by Ultrajaya (Indonesia) and heavy whipping cream from Anchor (Singapore). EasiYo unsweetened natural yoghurt premix (Indonesia) was applied in this study. Fructose syrup 55\% and xylitol were purchased from Bubblebee (Indonesia) and Xlear Inc. (USA), respectively.

\section{Preparation of Lemongrass Aqueous Extract and Powder}

Sun-dried lemongrass was ground using a miller. The extraction used 3:5 (v/v) ratio, where $1,800 \mathrm{ml}$ (or $450 \mathrm{~g}$ ) of lemongrass and $3,000 \mathrm{~mL}$ of distilled water were used. The extraction was performed at $70^{\circ} \mathrm{C}$ for 40 minutes with constant stirring. The extract was filtrated and evaporated for 1.5 hours. Lemongrass powder was prepared by grinding the sun-dried lemongrass using a FCT-Z100 miller (Fomac, Indonesia), until a fine powder was acquired.

\section{Rat Intestinal Glucosidase Inhibition Assay}

AGI activity measurement was done using the method by Gunawan-Puteri and Kawabata [5] with some modifications, i.e. the rat intestinal acetone powder was crushed in a cold mortar using potassium phosphate buffer ( $\mathrm{pH}$ 7.0) containing $5 \mathrm{mM}$ EDTA and $1 \%$ Triton $\mathrm{X}$. The mixture was homogenized using a homogenizer and centrifuged at $11,000 \mathrm{rpm}$ for 30 minutes.

\section{E. Rapid Heating Treatment}

The extract was heated at $70^{\circ} \mathrm{C}$ for 5 minutes, cooled down to $4{ }^{\circ} \mathrm{C}$ and stored overnight. Then, it was stored in a freezer for 3 hours before being evaluated.

\section{F. Long-Time Heating Treatment}

The extract was incubated at $86^{\circ} \mathrm{C}$ for 10 hours, and then stored at $4^{\circ} \mathrm{C}$ for 2 hours before AGI assay.

\section{G. Production of Ice Cream and Yoghurt}

The ice cream was produced using a simple ice cream recipe from CuisinArt Recipe Booklet using the ice cream maker ICE-100 (CuisinArt, USA). The yoghurt was produced using EasiYo Yoghurt Maker (EasiYo, New Zealand) and EasiYo unsweetened natural yoghurt premix with 10 hours of incubation. In both products, as a sugar substitute, a mixture of $25 \mathrm{ml} / \mathrm{L}(\mathrm{v} / \mathrm{v})$ fructose and $50 \mathrm{mg} / \mathrm{L}(\mathrm{w} / \mathrm{v})$ xylitol were added. Two lemongrass extract concentrations, $150 \mathrm{mg} / \mathrm{L}$ and
$1,500 \mathrm{mg} / \mathrm{L}$ were applied. AGIs activity of the fortified products used a modeling process, where the extract was given the same treatment as in yoghurt and ice cream processing.

\section{H. Hedonic Test}

Fortified ice cream and yoghurt product samples were given to 42 untrained panelists to assess their acceptance toward the products on a scale of 1 (extremely dislike) to 9 (extremely like).

\section{Statistical Analysis}

The results obtained are expressed as means \pm standard deviation of the mean. The slope test was used to determine the significance between aqueous extract and powder form of lemongrass. The Wilcoxon test was used to analyze the hedonic test result, along with ANOVA with Tukey-HSD as a post hoc test for the significance between physical properties. A $p$ value of $<0.05$ was considered significant.

\section{RESULTS AND DISCUSSION}

Two forms of lemongrass ingredients, aqueous extract and powder, were assessed to find a more suitable form for application in functional food. AGIs activities of both forms of lemongrass were tested against glucosidase enzyme activity in several concentrations and expressed in $\mathrm{IC}_{50}$ which is the concentration required to inhibit $50 \%$ of activities. As shown in Figure 1, lemongrass aqueous extract exhibited higher inhibitory activities expressed in lower $\mathrm{IC}_{50}(14.46 \mathrm{mg} / \mathrm{mL})$ compared to lemongrass powder $(76.49 \mathrm{mg} / \mathrm{mL})$.

Other than for indicating the activity strength, the $\mathrm{IC}_{50}$ data were also used to determine the amount of lemongrass ingredient to be added in the food product, where the amount equal to 10 and 100 -fold of $\mathrm{IC}_{50}$ was used. This means that lemongrass aqueous extract equivalent to $144.6 \mathrm{mg} / \mathrm{L}$ and $1,446 \mathrm{mg} / \mathrm{L}$ would be required, while lemongrass powder equivalent to 764.9 and $7,649 \mathrm{mg} / \mathrm{L}$ would be required. The calculation showed that lemongrass powder application as a food ingredient, though providing advantages in application practicality such as stability and storage efficiency, may not be able to reach the desired activity in the food product, since the required amount for application is higher than the possible amount to be applied as an ingredient. Additionally, during the AGI activity assessments, lemongrass powder was found to have water dissolution difficulties and might also have similar difficulties during mixing with other ingredients. Therefore, lemongrass aqueous extract was chosen as the application form in the food model.

\section{Alpha-Glucosidase Inhibitor Activity of Lemongras:}

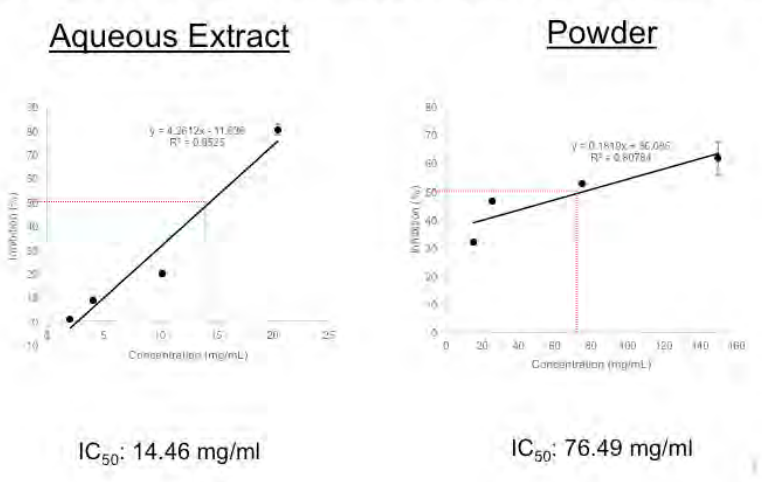

Figure 1. Alpha glucosidase inhibitory activities of lemongrass aqueous extract and lemongrass powder 


\section{A. AGIs Activities against Heating Treatment}

AGI stability of lemongrass aqueous extract of 10 and 100 -fold of $\mathrm{IC}_{50}$, with slight rounding $(150$ and $1,500 \mathrm{mg} / \mathrm{L})$ were tested against two types of heat treatment to model the processing of ice cream and yoghurt. The concentration of 150 $\mathrm{mg} / \mathrm{L}$ was applied to determine whether this $\mathrm{IC}_{50}$ concentration in a $100-\mathrm{mL}$ serving size would be able to exhibit inhibitory activity. On the other hand, the high concentration of $1,500 \mathrm{mg} / \mathrm{L}$ was found to be the maximum limit of added extract from a subjective tasting of product, where the aroma was perceived as 'too strong', hence, it would significantly reduce panelists' acceptance. In the first type of heat treatment, the lemongrass aqueous extract was exposed to rapid heating $\left(70^{\circ} \mathrm{C}, 5 \mathrm{~min}\right)$, cooling $\left(4^{\circ} \mathrm{C}, 12 \mathrm{~h}\right)$, then subsequent freezing $\left(-18^{\circ} \mathrm{C}, 3 \mathrm{~h}\right)$ to model pasteurization, pre-cooling, and freezing in ice cream processing. In the second type of heat treatment, the lemongrass aqueous extract was exposed to long-term heating $\left(86^{\circ} \mathrm{C}, 10 \mathrm{~h}\right)$ and cooling $\left(4^{\circ} \mathrm{C}, 2 \mathrm{~h}\right)$ to model high temperature incubation followed by cooling in yoghurt processing. AGI activity measurements showed that both treatments decreased AGI activities significantly, with more activity degradation found in lower concentration of extract. Moreover, the long-term heating in yoghurt seemed to affect the AGI degradation more abruptly (Table 1).

A previous study showed that lemongrass AGIs are better extracted at higher temperature up to $70^{\circ} \mathrm{C}$, with the optimum extraction time at 40 minutes [10]. However, it is important to also observe the AGI stability of the resulted extract towards subsequent processing as it will determine the activity in the consumed product. The results in this study were in coherence to that of previous studies showing that further exposure of lemongrass aqueous extract to short time high temperature treatment in spray drying condition (inlet $130^{\circ} \mathrm{C}$ ) reduced the inhibition activity up to $26.09 \%$ [10], while treatment of the extract with long-term high temperature in the evaporation process $\left(60^{\circ} \mathrm{C}, 8 \mathrm{~h}\right)$ reduced the inhibition activity up to $38.78 \%$. However, this is the first study showing the protection impact of the higher concentration of extract against activity degradation.

\section{B. Physical Properties of Ice Cream and Yoghurt}

Application of 150 and $1,500 \mathrm{mg} / \mathrm{L}$ lemongrass aqueous extract as an ingredient in the formula of yoghurt and ice cream showed interaction with other ingredients in the food model and affected the successful production, physical characteristic as well as the sensory properties of the ice cream and yoghurt. While ice cream using both concentrations of lemongrass extracts was successfully made, yoghurt fortified with higher extract concentration failed to form (Figure 2).

Table 1. Alpha glucosidase inhibitory activities of lemongrass aqueous extract upon heat treatment in ice cream and yoghurt processing model.

\begin{tabular}{cccc}
\hline $\begin{array}{c}\text { Heat } \\
\text { Treatment }\end{array}$ & $\begin{array}{c}\text { Lemongrass Extract } \\
\text { Concentration } \\
(\mathbf{m g} / \mathbf{L})\end{array}$ & $\begin{array}{c}\text { AGI } \\
\text { Inhibition } \\
\mathbf{( \% )}\end{array}$ & $\begin{array}{c}\text { AGI } \\
\text { Degradation } \\
(\%)\end{array}$ \\
\hline None & 150 & $36.58 \pm 0.37^{\mathrm{c}}$ & - \\
\cline { 2 - 4 }$($ Control) & 1,500 & $80.18 \pm 8.10^{\mathrm{d}}$ & - \\
\hline Ice Cream & 150 & $18.95 \pm 2.23^{\mathrm{b}}$ & 48.20 \\
\cline { 2 - 4 } Model & 1,500 & $66.74 \pm 2.80^{\mathrm{e}}$ & 16.76 \\
\hline Yoghurt & 150 & $15.12 \pm 1.64^{\mathrm{a}}$ & 58.67 \\
\cline { 2 - 4 } Model & 1,500 & $56.31 \pm 0.99^{\mathrm{f}}$ & 29.77 \\
\hline Values are expressed as mean \pm SD from triplicate measurement. Different letter in the same column
\end{tabular}

showed statistically significant difference $(p<0.05)$

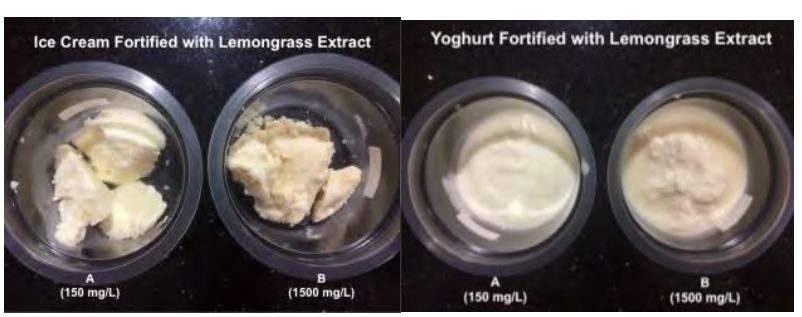

Figure 2. Ice cream and yoghurt fortified with $150 \mathrm{mg} / \mathrm{L}$

(A) and 1,500 mg/L (B) lemongrass aqueous extract.

Lemongrass aqueous extract is known to contain phenolics, tannins, and saponins [12-13], of which some of them showed an inhibition zone when tested on Lactobacillus acidophilus, L. rhamnossus, Streptococcus mutans, and S. oralis [14]. Though further confirmation is required, it is highly possible that the lemongrass aqueous extract also inhibits the growth of other lactic acid bacteria important for the fermentation in yoghurt, namely $S$. thermophilus and $L$. bulgaricus.

Comparison of the fortified product to control (ice cream made without lemongrass extract) showed ingredient interactions that affect the physical properties of the food model (Table 2). The addition of lemongrass extract was shown to reduce viscosity both in ice cream and yoghurt, though it increased the total soluble solid in ice cream. Despite the observable harder texture of lemongrass-fortified ice cream in comparison to the smoother texture of the control, lemongrass extract fortification increased the meltdown rate significantly in ice cream with increasing extract concentration. An interesting phenomenon was shown in the decreased value of overrun in ice cream fortified with 150 $\mathrm{mg} / \mathrm{L}$ lemongrass extract, while no significant decrease was observed in ice cream with higher concentration of fortification.

Typical ice cream consists of ice, air, fat, and matrix that form colloidal dispersion in the form of oil in water emulsion from the fat, solids from the ice crystal, and foams from the gas bubbles incorporated in the ice cream matrix, while yoghurt is a common example of water in oil emulsion [15]. Amongst the other ingredients, milk proteins are one of the most important ingredients to stabilize water-continuous emulsions and foams because they are surface active [16].

Table 2. Physical properties of ice cream and yoghurt fortified with lemongrass aqueous extract

\begin{tabular}{|c|c|c|c|c|}
\hline \multirow{2}{*}{$\begin{array}{l}\text { Model } \\
\text { Food }\end{array}$} & \multirow{2}{*}{$\begin{array}{c}\text { Type of } \\
\text { Physical } \\
\text { Properties }\end{array}$} & \multicolumn{3}{|c|}{$\begin{array}{c}\text { Value of physical properties in food } \\
\text { model* }\end{array}$} \\
\hline & & Control & $\begin{array}{c}\text { Fortified with } \\
150 \mathrm{mg} / \mathrm{L} \\
\text { extract }\end{array}$ & $\begin{array}{c}\text { Fortified with } \\
1,500 \mathrm{mg} / \mathrm{L} \\
\text { extract }\end{array}$ \\
\hline \multirow{4}{*}{$\begin{array}{c}\text { Ice } \\
\text { Cream }\end{array}$} & $\begin{array}{l}\text { Viscosity } \\
(\mathrm{cP})\end{array}$ & $\begin{array}{r}149.20 \\
\pm 2.23^{\mathrm{a}} \\
\end{array}$ & $\begin{array}{c}123.07 \pm \\
2.81^{\mathrm{b}}\end{array}$ & $\begin{array}{c}130.93 \pm \\
1.62^{\mathrm{b}} \\
\end{array}$ \\
\hline & $\begin{array}{l}\text { Meltdown } \\
\text { Rate }(\%)\end{array}$ & $\begin{array}{r}6.19 \pm \\
0.16^{\mathrm{a}}\end{array}$ & $22.47 \pm 0.36^{\mathrm{b}}$ & $27.38 \pm 0.32^{c}$ \\
\hline & $\begin{array}{l}\text { Total } \\
\text { Soluble } \\
\text { Solid } \\
\left({ }^{\circ} \text { Brix }\right) \\
\end{array}$ & $\begin{array}{c}11.60 \pm \\
0.15^{\mathrm{a}}\end{array}$ & $14.20 \pm 0.12^{\mathrm{b}}$ & $15.90 \pm 0.21^{\mathrm{c}}$ \\
\hline & $\begin{array}{l}\text { Overrun } \\
(\%)\end{array}$ & $\begin{array}{r}21.87 \pm \\
2.34^{\mathrm{a}} \\
\end{array}$ & $10.81 \pm 0.76^{\mathrm{b}}$ & $20.71 \pm 1.01^{\mathrm{a}}$ \\
\hline Yoghurt & $\begin{array}{l}\text { Viscosity } \\
(\mathrm{cP})\end{array}$ & $\begin{array}{l}4289.67 \\
\pm 7.37^{\mathrm{a}} \\
\end{array}$ & $\begin{array}{c}2841.67 \pm \\
1.53^{\mathrm{b}}\end{array}$ & $\begin{array}{c}782.33 \pm \\
3.06^{\mathrm{b}}\end{array}$ \\
\hline
\end{tabular}


The addition of lemongrass extract that contains phenolics, tannins, and saponins [12-13] may disrupt the protein surface activity due to denaturation [17], and consequently affect the formation and stability of fat and air bubbles in ice cream, thus disrupting the ability to form the colloidal dispersion. The disruption of emulsion formation was observed in the reduction of viscosity in ice cream and yoghurt. Reduction of the viscosity may also hinder foam formation due to rapid drainage of film between the air bubbles and coalescence of the bubbles [16]. Reduction of the foam formation capacity was highly correlated with a reduction in the overrun value, which is defined as the amount of bubbles incorporated in the ice cream [18-19]. Higher emulsion and foam formation capacities are known to prevent larger ice crystal formation, and therefore increase ice cream stability over heat, prevent rapid melting and produce a smoother texture of the ice cream [20].

Based on theories and observable data, it is then proposed that lemongrass extract denatured milk protein and its ability to hold the colloidal form in yoghurt and ice cream. Therefore, the lemongrass extract reduces the emulsion and foam formation which causes reduction in viscosity in ice cream and yoghurt and overrun value, and causes larger ice crystals, which leads to harder texture and higher meltdown rate.

\section{Sensory Evaluation}

Evaluation of sensory acceptance in ice cream fortified with 150 and $1,500 \mathrm{mg} / \mathrm{L}$ lemongrass extract and yoghurt fortified with $150 \mathrm{mg} / \mathrm{L}$ showed overall acceptance between score 6 "like slightly" to 7 "like moderately" (Table 3), indicating good acceptance of the products, though further comparison with commercial products and market tests are required to further conclude the food model acceptance. No significant difference in sensory acceptance was observed between ice creams fortified with 150 and $1,500 \mathrm{mg} / \mathrm{L}$ concentration except for its appearance. Several panelist comments revealed that darker color of ice cream with higher lemongrass extract might negatively affect the acceptance score for appearance due to its unclean appearance.

Table 3. Sensory acceptance of ice cream and yoghurt fortified with lemongrass aqueous extract.

\begin{tabular}{|c|c|c|c|}
\hline \multirow[b]{2}{*}{$\begin{array}{c}\text { Sensory } \\
\text { Properties } \\
\text { Observed }\end{array}$} & \multicolumn{3}{|c|}{ Sensory acceptance value* } \\
\hline & $\begin{array}{l}\text { Ice cream with } \\
150 \mathrm{mg} / \mathrm{L} \text { extract }\end{array}$ & $\begin{array}{c}\text { Ice cream with } \\
1,500 \mathrm{mg} / \mathrm{L} \text { extract }\end{array}$ & $\begin{array}{c}\text { Yoghurt with } \\
150 \mathrm{mg} / \mathrm{L} \\
\text { extract }\end{array}$ \\
\hline Appearance & $7.81 \pm 1.13^{\mathrm{a}}$ & $6.64 \pm 1.68^{b}$ & $7.60 \pm 1.15$ \\
\hline Aroma & $6.62 \pm 1.17^{\mathrm{a}}$ & $6.31 \pm 1.46^{\mathrm{a}}$ & $7.40 \pm 1.29$ \\
\hline Taste & $6.14 \pm 1.88^{\mathrm{a}}$ & $6.12 \pm 1.69^{\mathrm{a}}$ & $6.07 \pm 1.87$ \\
\hline Texture & $7.02 \pm 1.49^{\mathrm{a}}$ & $7.12 \pm 1.64^{\mathrm{a}}$ & $6.90 \pm 1.39$ \\
\hline Overall & $6.98 \pm 1.46^{\mathrm{a}}$ & $6.57 \pm 1.61^{\mathrm{a}}$ & $6.76 \pm 1.36$ \\
\hline
\end{tabular}

\section{CONCLUSION}

Lemongrass aqueous extract was found to be a possible application form of lemongrass as a functional ingredient with $\alpha$-glucosidase inhibitory (AGI) activity. Heating and cooling treatment to model ice cream and yoghurt processing decreased the activities with more abrupt degradation shown in longer heating treatment and lower concentration of lemongrass extract treated. Fortification of lemongrass extract in higher concentration caused failure in yoghurt formation. Fortification of lemongrass extract reduced the viscosity of both ice cream and yoghurt, increased meltdown rate and decreased overrun value, indicating lemongrass impact to the colloidal formation in ice cream and yoghurt. Sensory acceptance of successful ice cream and yoghurt produced in this study were between like slightly and like moderately, supporting further development of lemongrass application as a functional ingredient in such products.

\section{ACKNOWLEDGMENT}

This research project was supported by a grant from the Directorate General of Resources for Science, Technology and Higher Education of the Republic of Indonesia with contract number 0789/K4/KM/2018.

\section{REFERENCES}

[1] A. Y. Cheng, I. G. Fantus, "Oral antihyperglycemic therapy for type 2 diabetes mellitus", Can. Med. Assoc. J., vol. 172(2), pp. 213-226, 2005.

[2] F. A. van de Laar, P. L. Lucassen, L. P. Akkermans, E. H. van de Lisdonk, G. E. Rutte, C. Weel, " $\alpha$-Glucosidase inhibitors for patients with type 2 diabetes", Diabetes Care, vol. 28, pp. 154-163, 2005.

[3] C. E. Koop, "The future of medicine", Science, vol. 295 (5553), pp. 233.

[4] M. D. Gunawan-Puteri, M. R. Bhandar, J. Kawabata, "Indonesian medicinal plants and their anti-diabetic potencies", Functional foods for chronic diseases, vol. 4, pp. 110-120, 2009.

[5] M. D. Gunawan-Puteri, J. Kawabata, "Novel $\alpha$-glucosidase inhibitors from Macaranga tanarius leaves", Food Chem., vol. 123(2), pp 384389, 2010.

[6] T, Ieyama, M. D. Gunawan-Puteri, J. Kawabata, “ $\alpha$-Glucosidase inhibitors from the bulb of Eleutherine americana", Food Chem., vol. 128(2), pp. 308-311, 2011.

[7] M. D. Gunawan-Puteri, E. Kato, J. Kawabata, “ $\alpha$-Amylase inhibitors from an Indonesian medicinal herb, Phyllanthus urinaria", J. Sci. Food Agric., vol. 92(3), pp. 606-609, 2012.

[8] I. S. Arsiningtyas, M. D. Gunawan-Puteri, E. Kato, J. Kawabata, "Identification of $\alpha$-glucosidase inhibitors from the leaves of Pluchea indica (L.) Less., a traditional Indonesian herb: promotion of natural product use", Nat. Prod. Res., vol. 28(17), pp. 1350-1353, 2014.

[9] F. Santoso, C. Soedarma, G. A. Adiyoga, M. D. P. T. Gunawan-Puteri, H. Sutanto. In R. P. Nugrohedi, K. Ardanareswari, I. E. Vernandez, Eds., Proceeding of the $2^{\text {nd }}$ International Conference on Sustainable Global Agriculture and Food, August 2016, Semarang, Indonesia, Unika Soegijapranata. ISBN 978-602-6865-43.4. pp. 184-194, 2016.

[10] M. D. P. T. Gunawan-Puteri, B. Josopandojo, G. H. Adiyoga, I. S. Kartawiria, D. I. Widiputri, "Aqueous extraction optimization of $C$. citratus for development of food ingredients with alpha glucosidase inhibitory activities. In I. Sukmana, A. Ulvan, Eds., Integrated SciTech: The Interdisciplinary Research Approach Vol. 2. Research Institute and Community Service of Universitas Lampung, pp. 55 - 61, ISBN: 978-602-0860- 14-5, 2016.

[11] D. I. Widiputri, N. Mariana, B. Josopandojo, M. D. P. T. GunawanPuteri, I. S. Kartawiria, "Effect of pre-treatment processes and stability testing of lemongrass (Cymbopogon citratus) extract on $\alpha$-glucosidase inhibitor (AGI) and $\alpha$-amylase inhibitor (AAI) activities", Proceeding of International Postgraduate Symposium on Food, Agriculture and Biotechnology, August 2017, Mahasarakham, Thailand, Mahasarakham University, pp. 10-20, 2017.

[12] T. S. Geetha, N. Geetha, "Phytochemical screening, quantitative analysis of primary and secondary metabolites of Cymbopogon citratus (DC) Stapf. leaves from Kodaikanal hills, Tamilnadu", Int. J. Pharmtech Res., vol. 6(2), pp. 521-529, 2014.

[13] V. S. Nambiar, "Potential functions of lemongrass Cymbopogon citratus in health and disease", International Journal of Pharmaceutical \& Biological Archive, vol. 3(5), 2012.

[14] S. V. Ambade, B. J. Bhadbhade, "In vitro comparison of antimicrobial activity of different extracts of Cymbopogon citratus on dental plaque isolates", Int. J. Curr. Microbiol. Appl. Sci., vol. 4(7), pp. 672-681, 2015.

[15] R. M. Boom, “Emulsion: Principles and Preparation” in Food Material Science Principle and Practice, J. M. Aguilera, P. J. Lillford, Eds. New York: Springer, 2008, pp. 305-340.

[16] C. Clarke. The Science of Ice Cream. Cambridge, The Royal Society of Chemistry, 2004. 
[17] T. Ozdal, E. Capanoglu, F. Altay. "A review on protein-phenolic interactions and associated changes", Food Research International, vol. 51(2), pp. 954-970, 2013.

[18] A. Kilara, R. C. Chandan, Y. H. Hui, Ice cream and frozen desserts. Handbook of food products manufacturing, 2007, pp. 593-633.

[19] H. D. Goff, R. W. Hartel. Ice cream. Springer Science \& Business Media, 2013.

[20] E. Dickinson. Food emulsions and foams: stabilization by particles. Curr. Opin, Colloid Interface Sci., vol. 15(1-2), pp. 40-49, 2010. 